\title{
Jurnal

\section{Peranan Room Division Leader Dalam Melaksanakan Tugas Supervisor Di Housekeeping Department Hotel Rangkayo Basa Padang}

\author{
Amrisdi Pranata ${ }^{1}$, Ira Meirina Chair ${ }^{2}$ \\ ${ }^{1}$ Universitas Negeri Padang \\ ${ }^{2}$ Universitas Negeri Padang \\ email : amrisdipranata73@gmail.com,irameirinachair@fpp.unp.ac.id
}

\begin{abstract}
ABSTRAK
Latar belakang penelitian ini karena adanya beberapa masalah di Housekeeping Department Hotel Rangkayo Basa Padang, diantaranya yaitu morning briefing yang jarang dilakukan oleh room division leader kepada bawahan, tidak terdapatnya perencanaan kerja serta terdapat beberapa komentar negatif tamu melalui online travel agent tentang kebersihan kamar tamu. Jenis penelitian yang digunakan adalah deskriptif kualitatif. Penentuan informan yang dilakukan yaitu secara purposive sampling. Informan dalam penetian ini terdiri dari empat orang. Data didapatkan melalui wawancara dengan informan serta studi dokumentasi, selanjutnya data direduksi, penyajian data dan pengambilan keputusan.

Kesimpulan dalam penelitian ini yaitu : 1) Room division leader tidak melaksanakan perannya dalam hal perencanaan pekerjaan, pengarahan, pengawasan dan evaluasi kerja dimana tidak terdapat informasi mengenai kegiatan daily dan general cleaning, tidak mengecek logbook Housekeeping, tidak melakukan morning briefing sebelum bekerja, tidak memberikan arahan mengenai penggunaan peralatan kerja, tidak melakukan pengecekan pada area toilet musholla, tidak mengecek tempat penyimpanan alat dan bahan kerja, tidak melakukan evaluasi terhadap penggunaan peralatan kerja, serta tidak mengisi toilet checklist. 2)Room division leader telah melaksanakan perannya dalam hal koordinasi kerja, dimana room division leader memberikan room attedant report kepada room attendant dan menggunakan walkie talkie sebagai alat komunikasi dalam bekerja.
\end{abstract}

Kata kunci : Peran, Room division leader, Housekeeping Department 


\section{PENDAHULUAN}

Industri pariwisata di Indonesia merupakan salah satu sektor penghasil devisa yang terbanyak menghasilkan kontribusi, seperti pendapatan asli daerah (PAD), selain itu melalui pariwisata dapat memperluas lapangan kerja dan menambah wawasan budaya [1]. Salah satu sektor pariwisata yang berkembang pesat saat ini adalah industri perhotelan. Industri perhotelan merupakan salah satu bisnis yang begerak di bidang pelayanan jasa. Jasa yang di kelola berupa jasa penginapan, jasa pelayanan makan dan minum, serta jasa pelayanan lainnya. Menurut [2], "Hotel adalah penyedia jasa akomodasi berupa kamar-kamar di dalam suatu bangunan yang dapat di lengkapi dengan jasa pelayanan makan dan minum, kegiatan hiburan dan fasilitas lainnya secara harian dengan tujuan memperoleh keuntungan". Pelayanan tersebut diberikan melalui peran sumber daya manusia yang ada di dalamnya.

Menurut [3], mengatakan bahwa "Sumber Daya Manusia (SDM) adalah individu produktif yang bekerja sebagai penggerak suatu organisasi, baik itu dalam institusi maupun perusahaan yang memiliki fungsi sebagai aset sehingga harus dilatih dan dikembangkan kemampuannya". Maka dari itu hotel membutuhkan sumber daya manusia yang berkualitas, ditunjukkan oleh kemampuan karyawanan yang mampu melakasanakan tugas dan tanggung jawabnya dengan baik. Tugas merupakan satu kesatuan yang saling berkaitan antara tugas pokok dan fungsi yang harus dijalankan dengan penuh rasa tanggung jawab untuk mencapai suatu tujuan [4]. Salah satu hotel yang berusaha meingkatkan pelayanannya melalui pelaksanaan tugas oleh setiap karyawannya yaitu Hotel Rangkayo Basa Padang.

Hotel Rangkayo Basa Padang ialah salah satu hotel berbintang tiga di Kota Padang yang berlokasi di Jln. Hang Tuah No.211, Belakang Tangsi, Kecamatan Padang Barat, Kota Padang. Hotel ini memiliki prinsip syariah serta peraturan dan SOP yang telah ditetapkan oleh manajemen untuk dapat diterapkan dan dilaksanakan oleh setiap karyawan yang bekerja khususnya di Department Housekeeping. Department Housekeeping di Hotel Rangkayo Basa di pimpin oleh seorang Room division leader yang berperan sebagai Housekeeping Supervisor dengan dibantu oleh room attendant serta public area attendant. Menurut [5] "Supervisor adalah seorang manager pada tingkat bawah organisasi, yang harus mengawasi pegawai junior. Maka dari itu seorang supervisor harus mampu melaksanakan tugasnya sebaik mungkin.

Menurut [6] terdapat lima indikator tugas dan tanggung jawab seorang supervisor, yaitu "perencanaan pekerjaan, koordinasi, pengarahan, pengawasan, dan evaluasi". Selama melaksanakan praktek lapangan industri (PLI) di bulan Agustus hingga Desember 2020, penulis melakukan pra penelitian di Hotel Rangkayo Basa Padang, terdapat beberapa tugas dan tanggung jawab yang tidak dilaksanakan dengan baik oleh Room division leader yang berperan sebagai Hosekeeping Supervisor. Masalah tersebut yaitu Room division leader hanya melakukkan kegiatan morning briefing satu kali dalam sebulan dan juga pada saat hotel high occupancy saja, tidak terdapatnya perencanaan kerja berupa daily cleaning atau general cleaning oleh Room division leader kepada room attendant dan public area attendant, adanya komentar tamu melalui online travel agent yang menyatakan bahwa terdapat kamar yang kurang bersih, serta AC yang berisik dan baterai remote yang tidak diganti, terdapat area toilet musholla yang kotor karena tidak dibersihkan, status kamar yang lambat diperbaharui oleh room division leader, dan terdapat area housekeeping store yang kotor dan linen tidak di susun oleh room attendant.

\section{METODOLOGI}

Penelitian ini menggunakan jenis penelitian deskriptif dengan pendekatan kualitatif. Penelitian ini bertujuan untuk menganalisis peranan room division leader dalam melaksanakan tugas supervisor di Housekeeping Hotel Rangkayo Basa Padang. Penentuan informan yang dilakukan yaitu secara purposive sampling. Instrumen yang digunakan yaitu membuat pedoman wawancara berupa pertanyaan yang akan diajukan kepada Human Resources Manger, Room Division Leader, room attendant dan public area

attendant di Housekeeping Departement Hotel Rangkayo Basa Padang.Wawancara ini dilakukan dengan seperangkat pertanyaan yang disusun sistematis untuk memperoleh informasi secara lengkap. 
Penelitian ini menggunakan data premier dan data sekunder. Teknis alanisis data dengan cara mereduksi data, lalu menyajikan data dalam bentuk uraian singkat, kemudian membuat kesimpulan. Penulis terlebih dahulu mengambil kesimpulan awal yang bersifat sementara tentang peranan room division leader dalam melaksanakan tugas supervisor di Housekeeping Departement Hotel Rangkayo Basa Padang, setelah ditemukan bukti-bukti yang mendukung dan konsisten di lapangan dapat menjawab rumusan masalah yang dirumuskan, maka barulah dibuat kesimpulan yang sebenarnya, sehingga hasil penelitian jelas maksud dan tujuannya, barulah menerapkan suatu kesimpulan.

\section{HASIL DAN PEMBAHASAN}

\section{Perencanaan Kerja}

Peranan Room Division Leader dalam membuat perencanaan pekerjaan di Housekeeping Departement berupa pembuatan working schedule secara bulanan dan di tempel di Housekeeping Office, namun working schedule ini dapat berubah sesuai kondisi dan occupancy hotel. Namun perencanaan kerja nya hanya berupa memo yang di tempel dan catatan di logbook housekeeping serta waktu bekerja dimulai dari jam 7 hingga 4 sore. Berdasarkan observasi dilihat bahwa room division leader membuat working schedule untuk Housekeeping Departement dan menempel working schedule Housekeeping Office. Tetapi juga terlihat beberapa masalah diantaranya tidak terdapat perencanaan kerja berupa daily cleaning dan general cleaning, hanya ada memo yang ditempel di Housekeeping Office, serta logbook housekeeping tidak diisi lagi dan di cek oleh room division leader. Tidak ada waktu penyelesaian kerja agar menjadi lebih efektif

\section{Koordinasi}

Room division leader mempunyai target dan tujuan kerja seperti kegiatan general cleaning ballroom dan kamar tamu. Koordinasi kerja dilakukan dengan memberikan housekeeping report dan public area report kepada bawahan, serta berkomunikasi disaat kerja menggunakan walkie talkie. Berdasarkan observasi dilihat bahwa room division leader mempunyai target dan tujuan kerja yang jelas. Hal ini dibuktikan dengan adanya form housekeeping report yang bagikan kepada bawahan, serta selalu berkomunikasi menggunakan walkie talkie saat bekerja. Room division leader juga melakukan koordinasi dengan memeriksa pekerjaan bawahan disaat bekerja

\section{Pengarahan}

Room division leader jarang melakukan pengarahan kerja, berupa morning briefing. Morning briefing dilakukan saat terdapat kendala kerja dan saat high occupancy atau terdapat event yang akan diselenggarakan. Room division leader juga memberikan arahan kerja sesuai dengan SOP dan membatasi penggunaan chemical dengan tujuan saving cost. Berdasarkan observasi dilihat bahwa room division leader jarang melakukan morning briefing dengan karyawan housekeeping. Morning briefing dilakukan jika terdapat kendala kerja atau saat high occupancy. Serta room division leader kurang memberikan arahan mengenai penggunaan peralatan kerja, sehingga terdapat broom dan mop yang sudah patah.

\section{Pengawasan}

Room Division Leader berperan dalam melakukan pengawasan kerja di Housekeeping Departement, dengan cara berkeliling ke area kerja dan memantau langsung pekerjaan yang telah dikerjakan oleh bawahan. Room division leader juga mengecek ketersediaan alat dan bahan kerja yang telah digunakan. Berdasarkan observasi dilihat bahwa room division leader tidak melakukan pengecekan pada area toilet musholla, terdapat area toilet yang tidak kering dan tiusse toilte yang tidak diganti. Room division leader juga tidak mengecek tempat penyimpanan alat dan bahan kerja, terdapat checimal yang tidak disusun rapi dan janitor yang tidak rapi. 


\section{Evaluasi}

Room Division Leader melakukan penilaian kinerja setiap bulannya, lalu nanti di isi ke dalam form penilaian kinerja karyawan yang nantinya diberikan kepada HRD satu kali dalam setahun untuk penilian karyawan teladan dan promosi jabatan. Room division leader memperbaiki pekerjaan bawahan yang salah, dan menghemat penggunaan chemical dengan tujuan saving cost. Room division leader juga memberikan pujian dan apresiasi kepada karyawan yang telah bekerja dengan baik. Berdasarkan observasi dilihat bahwa room division leader melakukan evaluasi terhadap cara kerja bawahan dengan mengisi form penilaian kinerja yang akan diberikan kepada bagian HRD. Room division leader juga meperbaiki pekerjaan bawahan yang salah. Namun terdapat bebarapa masalah yaitu room division leader tidak melakukan evaluasi terhadap penggunaan peralatan kerja, sehingga terdapat peralatan kerja yang rusak dan tidak diganti, serta room division leader tidak mengisi toilet checklist. Dimana toilet checklist ini bertujuan untuk mengevaluasi pekerjaan yang telah dikerjakan bawahan.

\section{A. Pembahasan}

\section{Perencanaan Kerja}

Room division leader sebagian besar telah melaksakan perannya dalam hal perencanaan pekerjaan. Room division leader membuat working schedule setiap bulannya dan menempelnya pada housekeeping office, namun tidak terdapat informasi mengenai kegiatan daily cleaning dan general cleaning yang harus dilakukan oleh karyawan housekeeping. Serta room division leader juga tidak mengecek logbook mengenai pekerjaan yang telah diselesaikan dan yang belum terselesaikan. Hal tersebut sejalan dengan teori [7], "Perencanaan kerja adalah suatu proses mempersiapkan usaha atau kegiatan yang akan dilakukan secara sistematis dan logis untuk mencapai suatu tujuan yang telah ditetapkan sebelumnya secara efektif dan efisien"

\section{Koordinasi}

Room division leader telah melaksakan perannya dalam hal koordinasi kerja dengan baik. Room division leader memberikan room attedant report kepada room attendant untuk mengetahui jumlah kamar yang akan dibersihkan, menggunakan walkie talkie sebagai alat komunikasi dalam bekerja, serta room division leader juga memantau dan memeriksa pekerjaan bawahan disaat bekerja. Hal tersebut sejalan dengan teori [8] mendefinisikan "koordinasi sebagai proses pengintegrasian tujuan-tujuan dan kegiatan-kegiatan pada satuan-satuan yang terpisah (departemen atau bidang-bidang fungsional) suatu organisasi untuk mencapai tujuan organisasi secara efisien"

\section{Pengarahan}

Room division leader sebagian besar telah melaksakan perannya dalam hal pengarahan kerja. Room division leader memberikan arahan kerja sesuai dengan SOP dan membatasi penggunaan chemical dengan tujuan saving cost. Namun room division leader tidak melakukan morning briefing sebelum bekerja. Morning briefing dilakukan jika terdapat kendala kerja atau saat high occupancy. Serta room division leader tidak memberikan arahan mengenai penggunaan peralatan kerja, sehingga terdapat beberapa broom dan mop yang sudah patah dan tidak layak untuk digunakan saat bekerja. Hal tersebut sejalan dengan teori [6] "Tujuan pengarahan adalah supaya anggota seksi mendapat masukan yang jelas tentang tujuan kerja, target kerja yang di pakai, dan semua hal yang terkait dengan pekerjaan itu".

\section{Pengawasan}

Room division leader sebagian besar telah melaksakan perannya dalam hal pengawasan kerja.Room division leader berkeliling ke area kerja dan memantau langsung pekerjaan yang telah dikerjakan oleh bawahan. Room division leader juga mengecek ketersediaan alat dan bahan kerja yang telah digunakan. Namun room division leader tidak melakukan pengecekan 
pada area toilet musholla, terdapat area toilet yang tidak kering dan tiusse toilte yang tidak diganti. Room division leader juga tidak mengecek tempat penyimpanan alat dan bahan kerja, terdapat checimal yang tidak disusun rapi dan janitor yang tidak rapi. Hal tersebut sejalan dengan teori [9] "Pengawasan dapat diartikan sebagai suatu proses untuk menetapkan pekerjaan apa yang sudah dilaksanakan, menilainya, dan bila perlu mengoreksi dengan maksud supaya pelaksanaan pekerjaan sesuai dengan rencana semula".

\section{Evaluasi}

Room division leader sebagian besar telah melaksakan perannya dalam hal pengawasan kerja di Housekeeping Departement Hotel Rangkayo Basa Padang. Namun terdapat masalah yaitu room division leader tidak melakukan evaluasi terhadap penggunaan peralatan kerja, sehingga terdapat peralatan kerja yang rusak dan tidak diganti, serta room division leader tidak mengisi toilet checklist. Dimana toilet checklist ini bertujuan untuk mengevaluasi pekerjaan yang telah dikerjakan bawahan. Hal tersebut sejalan dengan teori [10] "Evaluasi merupakan kegiatan yang terencana untuk mengetahui keadaan sesuatu objek dengan menggunakan instrumen dan hasilnya dibandingkan dengan tolak ukur untuk memperoleh kesimpulan”.

\section{KESIMPULAN}

A. Room division leader tidak melaksanakan perannya dalam hal perencanaan pekerjaan, pengarahan, pengawasan dan evaluasi kerja di Housekeeping Departement Hotel Rangkayo Basa Padang, dimana tidak terdapat informasi mengenai kegiatan daily cleaning dan general cleaning, tidak mengecek logbook mengenai pekerjaan yang telah diselesaikan dan yang belum terselesaikan, tidak melakukan morning briefing sebelum bekerja, tidak memberikan arahan mengenai penggunaan peralatan kerja, sehingga terdapat beberapa broom dan mop yang sudah patah dan tidak layak untuk digunakan saat bekerja, tidak melakukan pengecekan pada area toilet musholla sehingga terdapat area toilet yang tidak kering dan tiusse toilte yang tidak diganti, tidak mengecek tempat penyimpanan alat dan bahan kerja, terdapat checimal yang tidak disusun rapi dan janitor yang tidak rapi, tidak melakukan evaluasi terhadap penggunaan peralatan kerja, sehingga terdapat peralatan kerja yang rusak dan tidak diganti, serta room division leader tidak mengisi toilet checklist, dimana toilet checklist ini bertujuan untuk mengevaluasi pekerjaan yang telah dikerjakan bawahan.

B. Room division leader telah melaksanakan perannya dalam hal koordinasi kerja di Housekeeping Departement Hotel Rangkayo Basa Padang, dimana room division leader memberikan room attedant report kepada room attendant untuk mengetahui jumlah kamar yang akan dibersihkan, menggunakan walkie talkie sebagai alat komunikasi dalam bekerja, serta room division leader juga memantau dan memeriksa pekerjaan bawahan disaat bekerja. 


\section{DAFTAR PUSTAKA}

[1] Suryani, Yulie. Aktivitas Sektor Pariwisata Terhadap Pendapatan Asli Daerah (PAD) di Kota Pariaman. Vol XI, Jilid 1, No.76. 2017

[2] Peraturan Menteri Pariwisata dan Ekonomi Kreatif Republik Indonesia Nomor 2 Tahun pasal 1. 2014

[3] Susan, Eri. Manajemen Sumber Daya Manusia. Jurnal Manajemen Pendidikan Islam. Vol 9, No. 2. 2019

[4] Rohyati, Eni. Penyusunan Tugas dan Tanggung Jawab Karyawan Pada Universitas X. Jurnal Psikologi, Vol 2, Hal 46-61. 2016

[5] Ricky. Penerapan Tugas Pengawasan Supervisor di DepartementHousekeeping Hotel Pangeran Beach Padang. Jurnal Ilmiah Berdasarkan Skripsi. 2016

[6] Bartono, Ruffino. Hotel Supervision. Yogyakarta : Andi. 2010

[7] As'ad, Ajmal. Pengaruh Perencanaan Kerja Terhadap Kinerja Karyawan. Jurnal Ilmu Ekonomi. 1(1) : 166-182. 2018.

[8] Handoko,T Hani Manajemen. Yogyakarta ; UGM. 2013

[9] Said, M.R, Radiman. Pengaruh Motivasi, Pengawasan dan Kepemimpinan Terhadap Disiplin Kerja Pegawai. Junal Ilmiah Magister Manajemen. Vol 2, no, 1 hal 117-128. 2019.

[10] Christian, dkk. Pengaruh Evaluasi Pekerjaan, Gaji, dan Fasilitas Kerja Terhadap Kinerja Pegawai Pada RS. Pancaran Kasih Manado. Vol.4 No. 5, hal 303-408. 2016. 